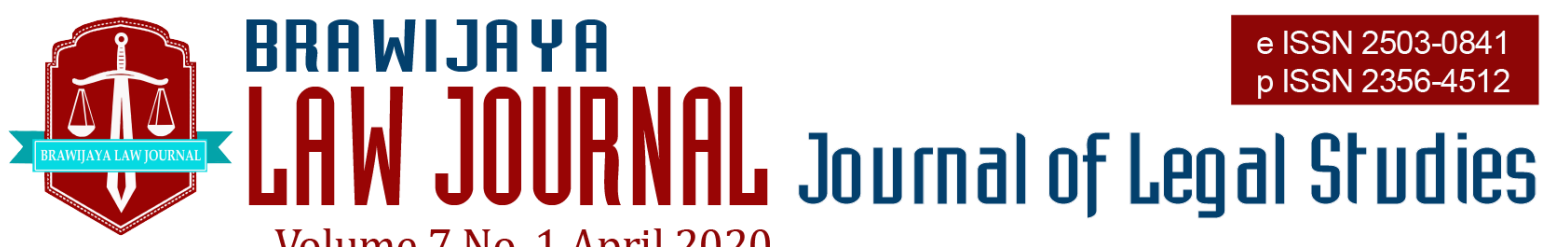

Volume 7 No. 1 April 2020

Nationally Accredited No. 30/E/KPT/2018 Dated 24th October 2018

This work is licensed under a Creative Commons Attribution-NonCommercial 4.0 International License

\title{
Piracy off The Coast of Indonesia: Potential Implications on The Craft Industry
}

\author{
Kalu Kingsley Anele \\ Cultural Heritage Preservation Research Institute (CHPRI), Pusan National University, Busan \\ Email: kkanele@gmail.com
}

Submitted : 2019-10-17 | Accepted : 2020-03-26

\begin{abstract}
Piracy off the coast of Indonesia may implicate on the craft industry; a significant non-oil foreign exchange earner in the country's economic development. For instance, piracy may affect tourists' use of cruise ship, exportation of craft products, and importation of raw materials and equipment for craft production in Indonesia. Consequently, it is imperative to repress piracy off the coast of Indonesia. In determining the potential effects of piracy to the craft industry, this paper addressed the linkages between piracy and craft and observed that piracy may pose a threat to the craft industry in Indonesia. Thereafter, the causes and effects of piracy on Indonesia's craft industry were interrogated. It was submitted that hijacking a vessel carrying craft items or a cruise ship may have economic, humanitarian and financial implications on Indonesian craft industry. The paper suggested measures to curb piracy off Indonesian coast and argued, inter alia, that updated piracy legal regime, strengthened institutional framework, and regional cooperation are central to combating piracy off the coast of Indonesia.
\end{abstract}

Keyword: Indonesia, craft, piracy, Indonesian coast, KUHP, LOSC, SUA Convention

\section{INTRODUCTION}

As the largest archipelagic country in the world, Indonesia is the fourth most populated country in the world endowed with lots of diverse natural resources, crafts, ethnicities, languages, cultural heritage, and cultures. ${ }^{1}$

This research was supported by the Ministry of Education of the Republic of Korea and the National Research Foundation of Korea (NRF2019S1A3055792).

1 Fadilah H. Arief, 'Indonesian crafts: the overlooked potential of geographical indication', (2016) 2(3)
Consequently, Indonesian government promotes and gives special attention to the development of craft industry in Indonesia through legislation and policies. ${ }^{2}$ For illustrative purposes, the Presidential Instruction No. 6 of 2009 strengthens the 
creative economy and the Presidential Regulation No. 92 of 2011 created a new ministry called the Ministry of Tourism and Creative Economy to promote the economic potentials of the creative economy in Indonesia. Consequently, craft was made an integral part of the creative economy in the country. According to report, Indonesia's craft market has significantly contributed to the overall creative industry export totaling 32.38 percent from 2010-2016, with an export value of US $\$ 7,797.6$ million in $2016 .^{3}$

More importantly, the government of Indonesia prioritised the tourism sector in its economic blueprint through the establishment of the National Medium-Term Development Plan (RPJMN) for 2015-2019 and the "Pengembangan Destinasi dan Industri Pariwisata" policy drive, ${ }^{4}$ which fosters the development of the craft industry. In fact, owing to the growth in the tourism sector and its attendant positive economic outlooks, the Indonesian government's tourism policy target was to attract 20 million tourists to the country by 2019 from 14 million tourists in $2017 .^{5}$ This paper submits that the combined effect of the policies to boost tourism and the creative economy is to strengthen the production, marketing, and exportation of Indonesia's craft products to the global craft market.

From the foregoing, the nature of traditional craft practices in Indonesia has gone beyond the conventional modes of production

3 See OPUS, Creative economy-outlook 2019 (BEKRAF, Jakarta, 2018) 48 and 'Financing opportunities in Indonesia's creative industry: final report', on IPSOS Business Consulting, April 2018, 16.

4 Patrice Ollivaud \& Peter Haxton, 'Making the most of tourism in Indonesia to promote sustainable regional development' on Economics Department Working Papers No. 1535, Organisation for Economic Co-operation and Development (OECD), 17 February 2019, 11.

5 Ibid, 4-8.

6 Fryza P. Pavitta, et al (eds.), Craft (Simpul Group: Jakarta, 2019) 16.

7 Ibid.

8 For details of the importance of maritime transportation in the economic development of Indonesia, including the craft industry and tourism due to technology, globalisation, and changing socioeconomic conditions in the country. Consequently, the over 700,000 handicraft business units that employ 1.32 million workers in Indonesia ${ }^{6}$ are producing craft products which are sold within the country (at both the rural and the urban markets). Further, due to mass production, Indonesian crafts are also sold at the global craft market with an export value of US\$823 million from January to November $2018,{ }^{7}$ thereby broadening its scope of economic potentials (see Figs. $3 \& 4$ below). As a significant non-oil foreign exchange earner in Indonesia, the craft industry exports diverse Indonesian crafts to the global craft market and maritime transportation is pivotal in this regard. ${ }^{8}$ In addition, the growth of tourism and the creative economy is a contributory factor to enhance and strengthen the global outreach of Indonesia's crafts. ${ }^{9}$ In light of this, Indonesia, like other neighbouring countries, depends on tourism and the exportation of craft products (essentially metal, wood, earthenware, and textile) for its economic development.

Historically, the Strait of Malacca has been the navigational route for merchants from India and China who traded on elephant tusks, rhinoceros horns, incense, silk, and medicinal herbs, while spices, like pepper, cloves, and nutmeg, and aromatics such as cinnamon and camphor were the major products that incentivised Western and Arab sailor-traders. ${ }^{10}$

(specifically maritime tourism), see generally Aristyo R. Darmawan, 'Indonesia's global maritime fulcrum: how can traditional coastal communities benefit from it?' <https://www.academia.edu/33642162/INDONESI AS_GLOBAL_MARITIME_FULCRUM_HOW_C AN_TRADITIONAL_COASTAL_COMMUNITIE S_BENEFIT_FROM_IT $>$ accessed 8 August 2019.

9 Lakhimi J. Chuta \& Mrinmoy K. Sarma, 'Commercialization of traditional crafts of South and South East Asia: a conceptual model based on review of literature', (2016) 5(2) IIM Kozhikode Society \& Management Review, 107.

10 Rheny W. Pulungan, 'The limitations of the international law on piracy and maritime terrorism: options for strengthening maritime security in the Malacca Straits', (submitted in total fulfilment of the requirements of degree of Doctor of Philosophy 
More importantly, the Strait of Malacca, a choke point, connects the China Sea to the Indian Ocean. Hence, maintaining a secured and safe navigation is key in view of the rising economic importance of Asia in the world. ${ }^{11}$ Nonetheless, about 3 decades ago, pockets of modern piracy attacks against Vietnamese boats occurred in the Gulf of Thailand, in addition to armed robbery attacks on vessels navigating through the Strait of Malacca. ${ }^{12}$ Moreover, it is pertinent to bring to the fore that piracy in the Southeast Asia has been in existence prior to the advent of European colonisation. By way of illustration, the description of pirates acts in the Strait of Malacca by a Buddhist Monk Shih Fa-Hsien, who travelled from Ceylon to China, a Mongolian official's written evidence of piracy in the Singapore Strait in the 14th century, the existence of Malacca Sultanate as a piracy haven, ${ }^{13}$ and contemporary piracy off the coast of Indonesia reveal the historical development of piracy in Asia. ${ }^{14}$

In fact, contemporary piracy acts in the Southeast Asia gained international prominence owing to the $9 / 11$ terrorist attacks in the United States (US). Consequently, it is observed that lax maritime security would embolden 'terrorists to hijack oil or natural gas

Melbourne Law School, the University of Melbourne, June 2014), 32.

11 Solvay Gerke \& Hans-Dieter Evers, 'The strategic importance of the Straits of Malacca', (Nusantara Papers No. 2, 2016), 2.

12 Hugh R. Williamson, 'New thinking in the fight against marine piracy: financing and plunder preempting piracy before prevention becomes necessary', (2013) 6 Case Western Reserve Journal of International Law 335, 336. Piracy legal instruments include The United Nations Convention on the Law of the Sea, adopted in 1982 and came into force 1994, 21 ILM (1982), 1261, hereafter referred to as the "LOSC" and The Convention for the Suppression of Unlawful Acts against the Safety of Maritime Navigation, adopted 10 March 1988, UNTS 1678, hereafter referred to as the "SUA Convention".

13 After the Portuguese seized Malacca in 1511, they occasionally loot and extort money from all the vessels bound for or coming from China's port. Xu $\mathrm{Ke}$, 'Contemporary maritime piracy in Southeast tankers and deploy them as "floating bombs" in the major ports, or sink hijacked ships to disrupt vessel traffic in the Straits of Malacca and Singapore (SOMS) which serve as a vital arteries of global commerce'. ${ }^{15}$ In view of Indonesia, the waters near the country's Riau Archipelago has become risky for navigation, while the ports of Tanjung Priok (Jakarta, Java), Dumai, Belawan (Sumatra), Balikpapan and Samarinda (Kalimantan) are prone to piracy attacks (note that piracy in this paper includes armed robbery against ships), especially when the vessels are at anchor. ${ }^{16}$ As an example of a typical piracy incident in Indonesia, the robbery of the Chemical Tanker Siteam Neptun, on 1 February 2012 at Batam Outer Anchorage (Riau Archipelago) occurred in the night. The pirates boarded the ship, stole ship's stores, and left the vessel without being seen. ${ }^{17}$

Whereas piracy affects the exportation of natural resources from Indonesia as oil and gas tankers are attacked, ${ }^{18}$ it potentially poses a threat to the export of craft items, including the importation of raw materials needed in Indonesian craft industry. Besides, piracy in the archipelagic waters of Indonesia affects tourists' use of international cruise ships to visit the country for tourism. This paper further argues that piracy potentially poses a threat to

Asia', a thesis submitted for the Degree of Doctor of Philosophy Southeast Asian Studies Programme, National University of Singapore, 2006, 36-37. See also Lukasz Stach, 'Neverending story? Problem of maritime piracy in Southeast Asia', (2017) 7(12) International Journal of Social Science and Humanity 723, 723-724.

14 L. Stach, ibid.

15 Ian Storey, 'Addressing the persistent problem of piracy and sea robbery in Southeast Asia', (2016) 30 Perspective, (ISEAS - Yusof Ishak Institute), 2.

16 Carolin Liss, 'Assessing contemporary maritime piracy in Southeast Asia: trends, hotspots and responses', Peace Research Institute Frankfurt (PRIF), PRIF Report No. 125, 2014, 18.

17 Ibid. See also the ICC/IMB Piracy and armed robbery against ships: report for the period 1 January - 31 December, January 2020, hereafter referred to as the ICC/IMB Piracy Report for 2019, 19.

18 Peter J. Maslanka, 'Securing Indonesia's energy future', (2015) 1 Journal of Energy Security, 9-10. 
the development of marine tourism in Indonesia. Consequently, Briandana, et al, observe that 'Indonesia has 17,499 island with a total beach length of ...81,000 km... which creates great potential for marine tourism in its territory'. ${ }^{19}$ In view of that, Indonesian government policy to strengthen maritime tourism to bolster its economic development ${ }^{20}$ will be derailed due to piracy off the coast of Indonesia.

Against this backdrop, this paper argues that strengthening the legal regime and adopting a proactive monitoring of Indonesian waters will go a long way in preventing piracy and its effects on the craft industry in the country. Thus, the paper will interrogate piracy off the coast of Indonesia, review Indonesian craft industry, and subsequently address the linkages between piracy and the craft industry in Indonesia. According to this author, it appears that sufficient conditions suggest that piracy may implicate on the craft industry in Indonesia as factors exist that make the craft industry vulnerable to piracy off the coast of Indonesia. Further, the paper will assess the legal regime for suppressing piracy in Indonesia and argue that the government of Indonesia should not only review its law to reflect the position under international law but also enforce them to repress the maritime crime. Subsequently, the paper will address the issues of causes and effects of piratical acts in Indonesia and suggest measures to repress piracy in the country. The paper is concluded by reiterating the importance of a secured maritime environment in the development and growth of the craft industry as an integral part of the economic development of Indonesia.

\section{LEGAL MATERIALS METHODS}

This paper uses the statute approach to assess the legal regime for suppressing piracy in Indonesia. The legal materials used in this paper include Indonesian criminal code, SUA Convention, LOSC, and Indonesian piracy regulations.

Moreover, to achieve the objective of this research, the paper interrogates piracy off the coast of Indonesia, reviews Indonesian craft industry, and addresses the linkages between piracy and the craft sector in Indonesia, especially through tourism. It is observed that circumstances exist which suggest that piracy may pose a threat to Indonesian craft industry.

\section{RESULT AND DISCUSSION Domestic and regional piracy attacks off the coast of Indonesia}

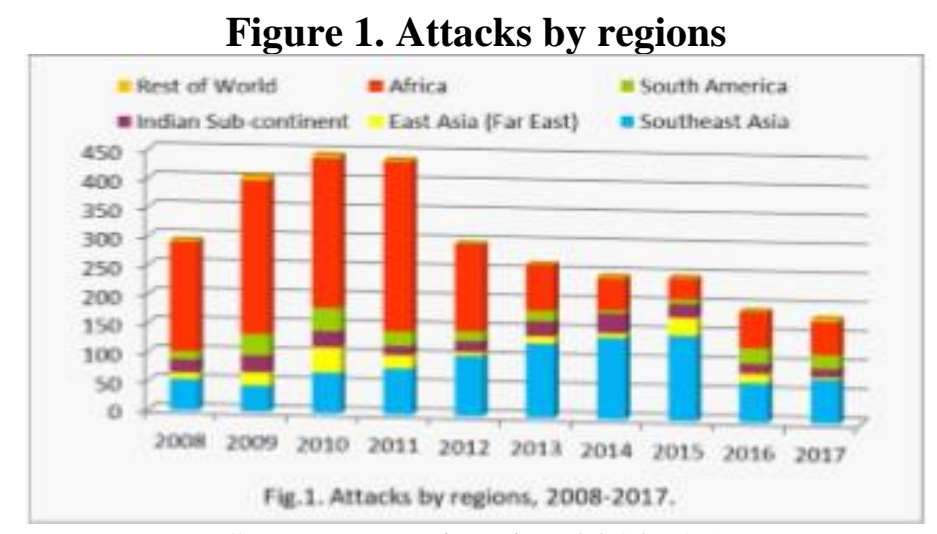

Source (Tumbarska, 2018, 19)

19 Rizki Briandana, et al, 'Promotion analysis of marine tourism in Indonesia: a case study', (2018) XXI (1) European Research Studies Journal, 602.

20 A.B. Sulistiyono, et al, ' $4 \mathrm{M}$ study to support Indonesia's maritime tourism development', (2017)
11(4) The International Journal on Marine Navigation and Safety of Sea Transportation, DOI: 10.12716/1001.11.04.20, 723, 724 .

4| Anele - Piracy off The Coast of Indonesia: Potential Implications on The Craft Industry 
Figure 2. Share of attacks by countries on the total world attacks (2008-2017)

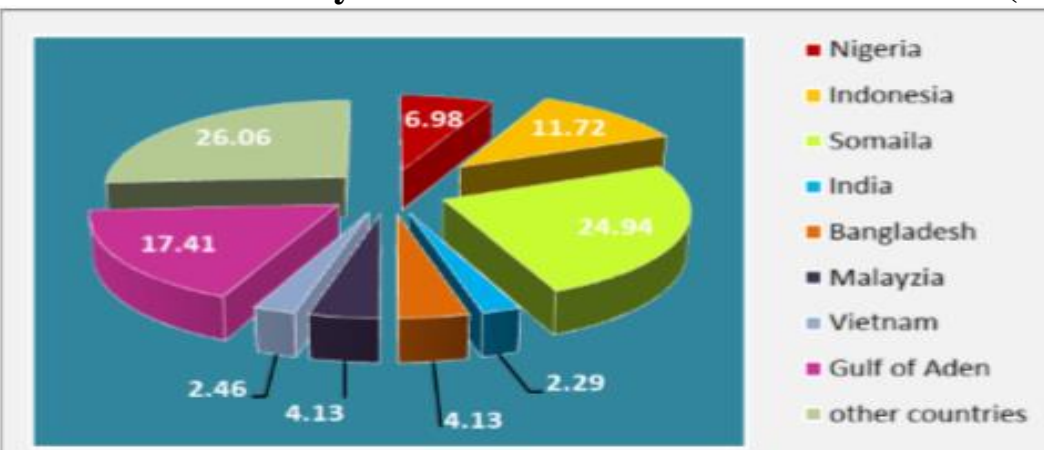

Fig. $2 a$. Share of the attacks by countries on the total world attacks in 2008-2012.

Source (Tumbarska, 2018, 19)

Table 1. Attacks by regions

\begin{tabular}{ccccccccccc}
\hline Region & $\mathbf{2 0 0 8}$ & $\mathbf{2 0 0 9}$ & $\mathbf{2 0 1 0}$ & $\mathbf{2 0 1 1}$ & $\mathbf{2 0 1 2}$ & $\mathbf{2 0 1 3}$ & $\mathbf{2 0 1 4}$ & $\mathbf{2 0 1 5}$ & $\mathbf{2 0 1 6}$ & $\mathbf{2 0 1 7}$ \\
\hline SE Asia & 54 & 45 & 70 & 80 & 104 & 128 & 141 & 147 & 68 & 76 \\
East Asia & 11 & 23 & 44 & 23 & 7 & 13 & 8 & 31 & 16 & 4 \\
Indian Sub-cont & 23 & 29 & 28 & 16 & 19 & 26 & 34 & 24 & 17 & 15 \\
South America & 14 & 37 & 40 & 25 & 17 & 18 & 5 & 8 & 27 & 24 \\
Africa & 189 & 266 & 259 & 293 & 150 & 79 & 55 & 35 & 62 & 57 \\
Rest of World & 2 & 6 & 4 & 2 & 0 & 0 & 2 & 1 & 1 & 4 \\
\hline Total & $\mathbf{2 9 3}$ & $\mathbf{4 0 6}$ & $\mathbf{4 4 5}$ & $\mathbf{4 3 9}$ & $\mathbf{2 9 7}$ & $\mathbf{2 6 4}$ & $\mathbf{2 4 5}$ & $\mathbf{2 4 6}$ & $\mathbf{1 9 1}$ & $\mathbf{1 8 0}$ \\
\hline \multicolumn{7}{c}{ Source (Tumbarska, 2018, 19) }
\end{tabular}

\section{a. Piracy off the coast of Indonesia}

In light of the foregoing, it is argued that Indonesia is one of the most important maritime countries in the world, especially when considered from its vintage geographical location. For example, Indonesia is situated between the Pacific and Indian Oceans, providing a central intersection for global shipping through the Strait of Malacca: 'a major shipping channel through which a large share of Asia's trade flow'. ${ }^{21}$ As the largest archipelago with thousands of islands and approximately eight million square kilometres of sea area, ${ }^{22}$ it is imperative for the government of Indonesia to secure these vast maritime areas to encourage the movement of tourists, craft items, and raw materials and equipment for producing craft items from one Island to another; including from Indonesia to other countries.

21 Lyle J. Morris \& Giacomo P. Paoli, A preliminary assessment of Indonesia's maritime security threats and capabilities (Rand Corporation, 2018), 15.
It is common knowledge that the spate of contemporary piracy in Southeast Asia commenced as a result of the economic challenges in the region. In fact, consequent upon the 1997-1998 Asian financial crisis, a lot of the riverine communities, especially from Indonesia and Thailand, witnessed an unprecedented level of unemployment and poverty. Additionally, there was stagnation in the government revenues of Southeast Asian countries which exacerbated the economic challenges in the region. And in Indonesia, the country's economic downturn culminated to the overthrow of President Suharto in 1998, 'ushering in a period of political turmoil and lawless in parts of the country. In these conditions, organized crime and piracy began to spread.' 23 Evidently, these factors contributed to the strengthening of piracy off the coast of Indonesia.

22 Ibid

23 Miha Hribernik, 'Multilateral counter-piracy cooperation in Southeast Asia: the role of Japan', 
It has been argued that the nature of Asian piracy is undergoing a transformational stage $^{24}$ which could affect the exportation of exquisite craft items and the importation of raw materials and equipment needed in the craft industry in Indonesia. Moreover, the movement of tourists from one Island to another, the use of international cruise ship by tourists to visit tourist destinations in Indonesia, and marine tourism will be hampered by piracy. Hence, Hribernik observes that piracy in Southeast Asia may 'become an increasing threat to freedom of navigation and the free flow of goods and commodities, which are transported in and out of Asia and across the globe'. ${ }^{25}$ So, this paper argues that if unchecked, Indonesian piracy will render the efforts of Indonesian government to enhance the craft industry, promote tourism and the creative economy, and bolster the maritime sector of the country nugatory.

In concluding this subhead, it is pertinent to analyse available data to explain the nature of Indonesian piracy and why it poses a threat to the country's craft industry. A glean at the ICC/IMB 2018 and ICC/IMB 2019 piracy reports reveal that from 2014 till 2019, the number of actual and attempted piracy off the coast of Indonesia is 100 (2014), 108 (2015), 49 (2016), 43 (2017), 36 (2018), ${ }^{26}$ and 25 (2019). ${ }^{27}$ This author observes that though the number of actual and attempted piracy attacks is dwindling, the waters of Indonesia remain dangerous for navigation. More so, compared to other Southeast Asian countries, piratical acts off the coast of Indonesia remain rife (see Figure 2 above). The import of this is that the exportation of Indonesian craft items and the importation of raw materials by Indonesian

(2017) 17(3) Pacific Forum CSIS Issues \& Insights, Honolulu, Hawaii, March 2017, 4.

24 Ibid at 8.

25 Ibid at 9.

26 ICC International Maritime Bureau (IMB) 'Piracy and armed robbery against ships: report for the period 1 January - 31 December 2018', January 2019, hereafter referred to as the 'ICC/IMB Piracy Report for 2018', 6.

27 ICC/IMB Piracy Report for 2019, 5. craft industry may be jeopardised, especially when juxtaposed with the changing nature of piracy in Southeast Asia. Also, piracy impedes tourism by adversely affecting the movement of tourists not only from one Island to another in Indonesia but from other countries to Indonesia. It is submitted that piracy also affects marine tourism in the country. And from a broader perspective, Indonesian piracy will impede the realisation of the President's policy of 'reinvigorating Indonesia's maritime identity, managing the country's marine resources, strengthening its maritime defence capability, intensifying maritime diplomacy, and improving interisland connectivity'. ${ }^{28}$

\section{b. Regional piracy}

Having briefly addressed piracy off the coast of Indonesia, it is necessary to highlight some of the activities of pirates at the regional level, especially in Southeast Asia (see Table 1 above). It is beyond any contestation that piracy is rife in Southeast Asia which involves opportunistic sea-robbery of small-scale attacks and sophisticated organised acts directed to hijacking vessels. These piratical acts in this region have been linked to the exploitation of the security limitations in the maritime environment and the existence of political, social, and economic challenges that create an enabling environment for piracy to thrive. In fact, it is argued that the following factors contributed to piracy in the region, to wit, over-fishing, lax maritime regulations, the existence of organised crime syndicates, the presence of radical politically motivated groups, and widespread poverty. ${ }^{29}$

From a global standpoint, the hijack of the Sirus Star off the Kenyan coast by Somali

28 Dedi Dinarto, 'Indonesia's blue economy initiative: rethinking maritime security challenges', RSIS Commentary No. 206, 1 November 2017 <https://www.rsis.edu.sg/wpcontent/uploads/2017/11/CO17206.pdf> accessed 26 July 2019.

29 "The roots of piracy in Southeast Asia", APSNet Policy Forum, 22 October 2007, 2 https://nautilus.org/apsnet/the-roots-of-piracy-insoutheast-asia/ accessed 26 July 2019. 
pirates on the 17th of November 2008 signalled not only the economic impact of piracy but also the vulnerability of vessels navigating through global sea routes. ${ }^{30}$ Consequent upon the success of global piracy, the number of hijacked ships, kidnapped crews, expensive ransom negotiations, and loss of life became increasingly high. And as observed by Burlando, et al, '(a)s merchant ships are attacked and trade flows disrupted, the cost of transporting goods through pirate waters increases, possibly discouraging trade through these regions. ${ }^{31}$

A cursory look at Figure 1 and Table 1 above shows that piratical attacks are rife in Africa and Southeast Asia. It is interesting to note that in Africa, the Gulf of Aden and the Gulf of Guinea are piracy hotspots. Although the Gulf of Aden was once the most piracy infested water in the world for many years, the Gulf of Guinea is presently the most dangerous navigational route in the world, especially the waters of Nigeria. Like the Gulf of Aden, Southeast Asia also witnessed an increase in piracy attacks, which has subsequently gone down. However, from the perspectives of states, the coast of Nigeria currently remains the most dangerous waters in the world. ${ }^{32}$ In closing, a careful assessment of Figure 2 above reveals that the coasts of Nigeria and Indonesia are inundated with piracy activities.

\section{Overview of the craft industry and its linkages to piracy in Indonesia \\ a. Indonesian craft industry}

Figure 3. Indonesian craft exports

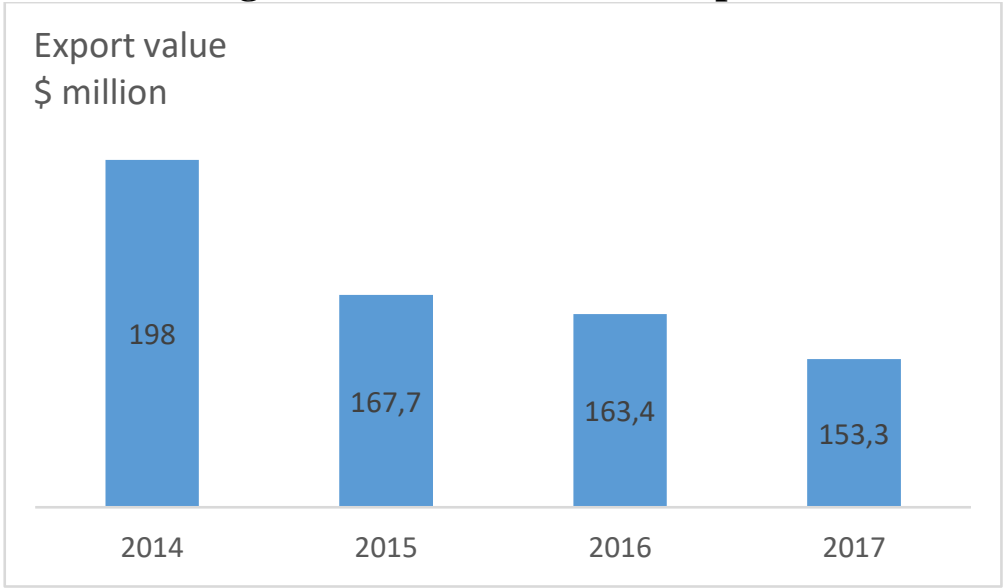

Source ("Indonesia sourcing: craft gift 2018", 2019, 7)

30 Jill Harrelson, "Blackbeard meets blackwater: an analysis of international conventions that address piracy and the use of private security companies to protect the shipping industry", 5(2) American University International Law Review, 283, 284 (2010).
${ }^{31}$ Alfredo Burlando, et al, "The trade consequences of maritime insecurity: evidence from Somali piracy", Munich Personal RePEc Archive (MPRA), 24 October 2014, 2.

32 The ICC/IMB Piracy Report for 2019, 5. 
Figure 4. Indonesian export by products

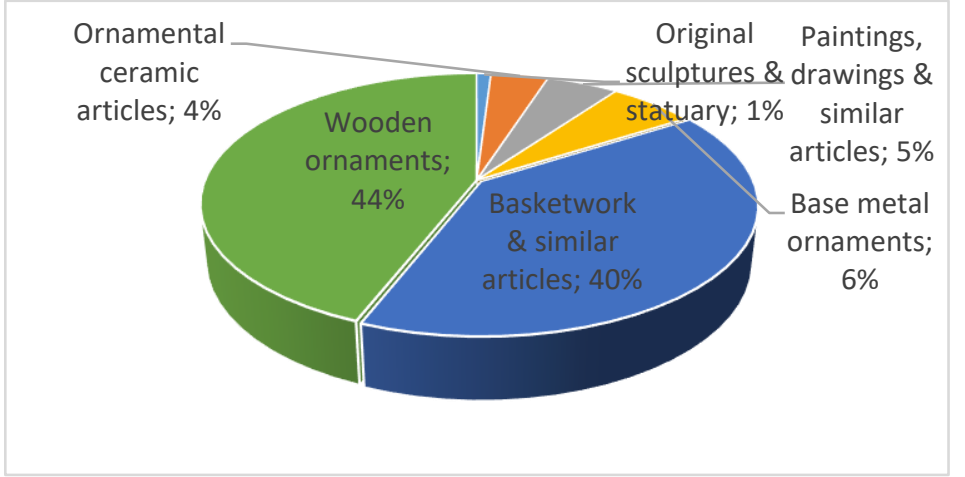

Source ('Indonesia sourcing: craft gift 2018', 2019, 7)

Figure 5. Indonesia: Direct Contribution of Travel \& Tourism to GDP
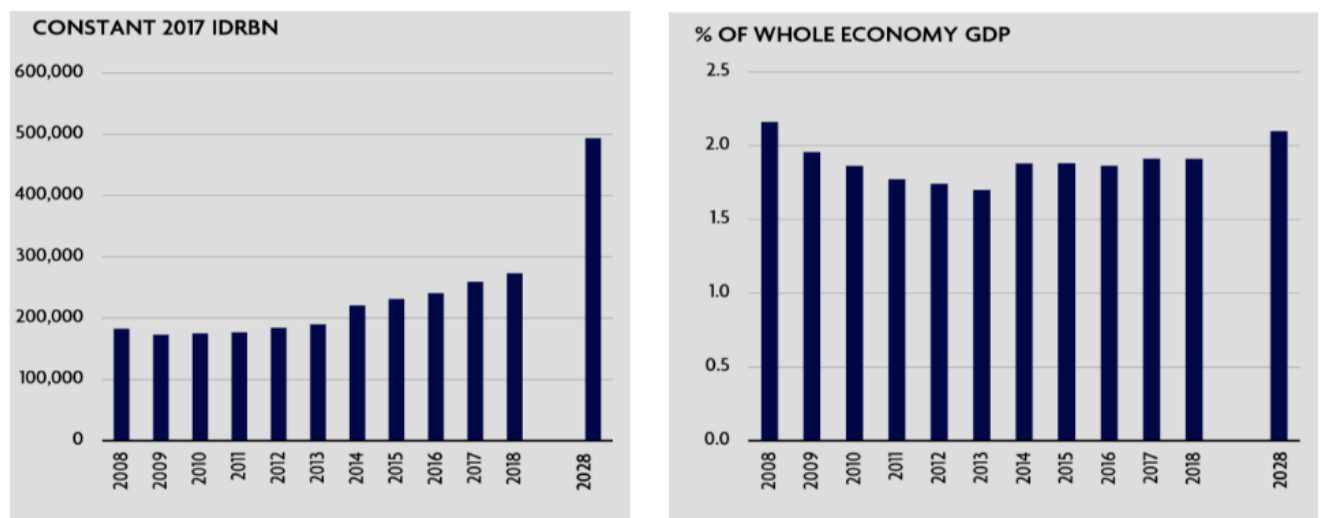

Source (Travel \& tourism, 2018, 3)

In light of the diverse ethnic nationalities in Indonesia, there are many cultures, languages, cultural heritage, and crafts in the country. In fact, each ethnic group has its unique crafts. For example, whereas the Batak ethnic group is known for their Batak Toba traditional houses, ulos (textile weaving), padung-padung (traditional jewelries: metal craft), the Javanese are globally known for their batik textile crafts. The exportation of these crafts contributes to the economic development of Indonesia. ure 3 above reveals the export values of most of Indonesian crafts from 2014 to 2017 and Figure 4 above also throws more light on the export value of the different crafts in Indonesia. Reflecting on piracy, this author argues that if left unchecked,

33 For example, the government of Indonesia has created many policies to boost the batik industry in the country. See generally, Christina Tri Setyorini, et $a l$, 'Strengthening the internal factors of Batik cluster the current maritime insecurity off the coast of Indonesia due to the activities of pirates will adversely implicate on the exportation of these craft items with its attendant effect on Indonesian economy.

The import of the existence of these crafts (see Figs. $3 \& 4$ above) is that there are many artisans in Indonesia and the government of Indonesia has continued to support the craft industry through policies and programmes. Some of the mechanisms utilsed by the Indonesian government to achieve this goal is through the introduction and support for craft small and medium enterprise (SMEs), ${ }^{33}$ promotion of the tourism sector, and introduction and support of the creative economy. The hallmark of the craft industry in

SMEs in Indonesia: a case of six districts in SouthCentral Java', (2013) 3(1) International Journal of Business, Humanities and Technology 21, 21-28. 
Indonesia is the recognition of batik as the cultural heritage of the country by United Nations Educational, Scientific and Cultural Organisation (UNESCO) on the 2nd of October 2009. ${ }^{34}$ Lending credence to the importance of craft in Indonesia, the government of Indonesia introduced a strategy to promote batik as a soft power instrument in Southeast Asia (batik diplomacy). ${ }^{35}$

Closely linked to the foregoing is the pivotal role the craft industry plays in both the tourism sector and the creative economy in Indonesia. Consequent upon the diverse ethnic groups and cultural heritage in Indonesia, there are many tourist sites where craft products are sold as souvenirs to both local and international tourists in Indonesia. ${ }^{36}$ Thus, statues, woodcarvings, metal carvings, paintings, batik textile (including other batik items like bags), ulos, and earthenware are some of the items that are exported to other countries and also sold as souvenirs to tourists in Indonesia. The inclusion of craft as part of the creative economy in Indonesia has led to the promotion and support for the production and marketing of craft items in the country. ${ }^{37}$ Figure 5 above reveals the linkage between tourism and travel and their impact on the Indonesian economy as well as the exportation of craft items.

34 See Asri Laksmi Riani, et al, "The acceleration of traditional Batik (creation and combination) through integrated management to support the acceleration in regional economic development', (2016) 4(4) Strategic Management Quarterly DOI: 10.15640/smq.v4n4a4, 53, 54.

35 Syaprin M. Zahidi, 'Batik as Indonesian public diplomacy in ASEAN Economic Community (AEC)', (2017) 3(2) International Journal of International Relations, Media and Mass Communication Studies 1, 8.

36 Currently, I am in possession of a brochure containing the cultures and cultural heritage cites in Sumatra that attract tourists to the area. See generally, Historical \& Culture, Sumatera Utara e-Brochure. (Copy of this material is on file with this author).

37 Iwan K. Subagja, 'Creative industry competitiveness in Indonesia (study on creative industry map)', International Conference on Sustainable Development Goals 2030 Challenges and its Solutions, 11-12 August 2017, pp. 157-159.
Specifically, piracy poses a threat to leisure crafts and yachts that may be used to navigate to Indonesia for tourism and other reasons. ${ }^{38}$ Consequently, due to the threat posed by pirates to navigation, those engaged in leisure sailing (cruise ships and yachts) in high risk waters have been enjoined to make contact in advance with the naval/military authorities. The implication of this is that piracy is a potential threat to their safety. ${ }^{39}$ With the target of the Indonesian government to attract about 20 million tourists to the country which is facilitated by the growing creative economy, this paper observes that piracy may impede the realisation of this target.

\section{b. The linkages between Indonesian craft and piracy}

It is acknowledged that piracy may be executed by individuals engaged in periodic acts. Nevertheless, it 'can also involve small and medium-sized groups with substantial, hierarchical organizational structures'. 40 Research suggests that collusion between pirates and government authorities contributes to the growing incidents of piracy in Southeast Asia. ${ }^{41}$ Instances abound where corrupt customs officials, port employees, or crewmembers divulge information on vessels

38 See Nebojsa Nikolic \& Eduard Missoni, 'Piracy on the high seas-threats to travelers', (2014) 20(5) Journal of Travel Medicine, DOI: 10.1111/jtm.12051, 313, 3143-315. BMP 4, Best Management Practices for Protection Against Somalia based pirates, (Version 4 - August 2011, Whiterby Publishing Group Ltd, 2011) 71.

39 See BMP 4, ibid and N. Nikolic \& E. Missoni, ibid. Some of the rare craft items acquired by tourists are exported through the sea. For more detailed analysis of tourism and traveling in Indonesia, see generally, Travel \& tourism: economic impact 2018 Indonesia, (World Travel \& Tourism Council, March 2018).

40 Ursula E. Daxecker \& Brandon C. Prins, 'The politicization of crime: electoral competition and the supply of marine piracy in Indonesia', (2016) 169 Policy Choice, DOI 10.1007/s11127-016-0374-z, 375, 378.

41 Justin V. Hastings, 'Understanding maritime piracy syndicate operations', (2012) 21(4) Security Studies https://doi.org/10.1080/09636412.2012.734234, 683, 689. See ibid at 379. 
and cargo manifests to pirates, coupled with the existing ties between criminal actors and various levels of the state bureaucracy that served as a form of regime maintenance. ${ }^{42}$ This paper argues that under these circumstances, it will be easy for pirates to obtain information about vessels carrying exquisite crafts items from Indonesia to other countries and hijack the vessels for the purposes of selling the cargo in the black market.

As a corollary to the above, it appears that a crewmember or crewmembers could provide information about the cargo of a vessel and further proffer steps to selectively open containers or holds, especially where there are high value cargoes on board. This implies prior knowledge of the cargo manifest and it confirms the connection between pirates and seafarers. This act may also be executed by perpetrators who 'previously had access to the ship as employees of a shore-based contractor'. ${ }^{43}$ In relation to the craft industry, the clearing and forwarding agent or port official with the knowledge of the value of the craft items for exportation or imported expensive equipment and raw materials needed in craft production may be the person leaking information to the pirates.

In his view, Bateman stated the inconvenient truth about piracy which lends credence to the linkage between piracy and the craft industry by observing that aside from pirates, other organisations benefit 'from piracy and exploit the threat of piracy to promote their own interests.' ${ }^{44}$ Using piracy and the craft industry in Indonesia as a case study, it is significant to note that there may be some artisans who would connive with pirates

42 Daxecker \& Prins, above n 36.

43 Catherine Z. Raymond, Piracy in Southeast Asia: new trends, issues and responses (Institute of Defence and Strategic Studies No. 89, Singapore, October 2006) 4.

${ }^{44}$ Sam Bateman, 'Sea piracy: some inconvenient truths', 2010, 14 <https://www.peacepalacelibrary.nl/ebooks/files/U NIDIR_pdf-art2960.pdf> accessed 31 July 2019.

45 For linkage between piracy and election that could lead to political and civil unrests due to election in to hijack vessels carrying craft products, raw materials and equipment for craft production due to either being unsuccessful in their craft production because stiff competition from both local and international craft companies or dissatisfied with the policies and programmes of the government and the craft industry. Moreover, such dissatisfied artisans may engage in piracy to hijack vessels conveying craft items from Indonesia to other countries or ships bringing raw materials and equipment needed in craft production from other countries to Indonesia.

Further, in linking piracy to the craft industry in Indonesia, it becomes necessary to consider the motives behind piracy and the economic factors that engender the crime. It is a widely known fact that poverty, loss of jobs, especially by fishermen, and civil and political unrests are some of the factors that lead to piracy. ${ }^{45}$ The loss of jobs by fishermen or the decline of profit in the fishing industry could trigger fishermen to become pirates in Indonesia. ${ }^{46}$ Also, income inequality could be an incentive for Indonesian pirates to hijack container vessels with rare craft items as cargo. Thus, it has been opined that the "multi-faceted interaction between piracy and trade ...calls into question the notion of the pirates as a mere predator, feeding parasitically off the toil and enterprise of others'. ${ }^{47}$ Further, it has been observed that piracy is "not apart from but a part of the economies of trade and seafaring. Pirates, like merchants, responded to market signals and economic incentives, and performed regular transitions from one form of maritime activity to another.' 48

Indonesia, see generally, Daxecker \& Prins, above $\mathrm{n}$ 36, 375-393.

46 For the impact of the decline in the profitability of fishing as coterminous to piracy in Indonesia, see generally Sebastian Axbard, 'Income opportunities and sea piracy in Indonesia', (2016) 8 (2) American Economic Journal: Applied Economics, 154, 154194

47 Sebastian R. Prange, 'Asian piracy', (2017) Indian Ocean Studies, DOI: 10.1093/acrefore/9780190277727.013.32, 1, 4.

48 Ibid. 
Another plausible reason to suggest a connection between piracy and the craft industry in Indonesia is the nature of bureaucracy that operates in the country's maritime domain consequent upon the number of government institutions monitoring activities in the maritime sector in the country. Against this backdrop, Suseto, et al observe that the 'mushrooming of illegal activities at sea is also due to inefficient bureaucracy practiced in Indonesia. There is simply too many departments involved in handling illegal activities at sea. ${ }^{49}$ For example, there are about 12 maritime agencies in Indonesia with overlapping jurisdictions. However, BAKAMLA (Badan Koordinasi Keamanan Laut) (Indonesian Maritime Security Coordinating Agency), which was established in 2014, is the coordinating institution for these agencies. ${ }^{50}$ This situation creates an enabling environment where bribery and corruption fester and facilitate the leaking of information about the worth of craft items and the vessel conveying them from the authorities to pirates.

In furtherance of the above, it is submitted that the separatist group, Gerakan Aceh Merdeka (GAM), engages in piracy and other illicit activities like illegal logging and mining, organised prostitution, drug production and distribution and gambling. ${ }^{51}$ Against this backdrop, it will be easy for GAM members to use their contacts from both the government and the private sector to be apprised of the exportation of exquisite

49 Such government institutions include National Coordinating Body for Ocean Safety; the National Coordinating Body for Ocean Safety; the Ministry of Marine Affairs and Fisheries; the Ministry of Forestry; the Ministry of Energy and Mineral Resources; the Ministry of National Education, the Ministry of Transportation and Communications; the State Ministry for Environment; the Indonesian Navy; the Indonesian Air Force; the Marine Police; the Directorate General of Immigration; and the Directorate General of Customs. See Buddy Suseto, et $a l$, 'The need to reform Indonesia's maritime strategy: a review', (2018) 50(2) Indonesian Journal of Geography. DOI: http://dx.doi.org/10.22146/ijg.27954, 145, 149.

50 Muhamad Arif \& Yandry Kurniawan, 'Strategic culture and Indonesian maritime security', (2018)
Indonesian craft products or the importation of raw materials required in the production of Indonesian crafts. More so, given the fact that most of the piracy acts off the coast of Indonesia are opportunistic in nature, GAM may inadvertently target and hijack vessels carrying Indonesian craft items, thereby affecting the revenue derivable from the sale of the items in the global craft market.

At this juncture, the inability of the government of Indonesia to effectively optimise the abundant marine resources also create a conducive environment where pirates can hijack vessels with craft items as cargo. It must be emphasised that waters 'between and surrounding Indonesia's islands have yet to be used as modality to secure territorial integrity and national economic development.' ${ }^{52}$ The obvious vulnerability of Indonesian waters encourages criminal elements to 'exploit the lack of defence to smuggle goods and people to and from Indonesia and involve in other transnational criminal activities.' 53 The susceptibility of Indonesian maritime sector is worsened by 'the government's stance to reject the presence of external powers despite the lack of operational capabilities of the country's maritime security apparatus.' 54 The implication of this situation is that pirates can hijack vessels carrying craft items or equipment or raw materials needed for craft production in order to sell them at the black market.

5(1) Asia \& The Pacific Policy Studies, doi: 10.1002/app5.203, 77, 87. Hadyu Ikrami \& Leonardo Bernard, "Indonesia's maritime law: national enforcement \& regional cooperation", 5th APOLIA Conference, 16 June 2017, Da Nang, Vietnam <https://cil.nus.edu.sg/wpcontent/uploads/2017/08/Ikrami_Bernard_2017-

APOLIA-Conference_FINAL.pdf $>$ accessed 30 November 2019.

51 Senia Febrica'Explaining Indonesia's participation in maritime security cooperation', (submitted in fulfillment of the requirements for the degree of Ph.D, School of Social Sciences, University of Glasgow, 2014), 61-62.

52 M. Arif \& Y. Kurniawan, above n 50 at 80.

53 Ibid.

54 Ibid. 


\section{c. Logistics, craft, and piracy in Indonesia}

It is beyond any contestation that through transportation, logistics plays a key role in the tourism industry. As an essential component of the tourism industry and its development, security in transportation plays a significant role in influencing the satisfaction of tourists with the tourist destination. ${ }^{55}$ This is in line with Indonesian government policy for national logistic system achievement ${ }^{56}$ which will promote the economic and infrastructural development of the country as well as enhance the movement of tourists from one island to another. Additionally, a secured transport system facilitates the exportation of Indonesian crafts and the importation of raw materials and equipment for craft production.

More so, the existence of about 30 main ports, 200 collector ports, and 1,000 feeder ports in Indonesia is a testament of the importance of maritime transportation to the country. ${ }^{57}$ These ports are central to the movement of people and cargo from one Indonesian island to another and from one country to Indonesia (also from Indonesia to other countries). The import of this is that foreign tourists visiting Indonesia through the sea on cruise ship may navigate through Indonesian waters and berth at the country's ports. On account of piracy, such trip will be prone to the threat of piracy attacks. ${ }^{58}$ More importantly, owing to Indonesian government efforts to develop the craft industry, it becomes necessary to export Indonesian crafts to other countries, while importing from other countries raw materials and state of the art facilities required for the production of Indonesian crafts. These economic activities

55 Anjali R. Virkar \& Prita D. Mallya, 'A review of dimensions of tourism transport affecting tourist satisfaction', (2018) IX(1) Indian Journal of Commerce \& Management Studies DOI: 10.18843/ijcms/v9i1/10, 72.

56 Presidential Regulation No. 26, 2012. See also John Malisan, Intermodal integration in Indonesia, Research \& Development Agency, Ministry of Transportation

<http://www.uncrd.or.jp/content/documents/7ESTP3-3.pdf $>$ accessed 5 September 2019. maybe encumbered by piracy off the coast of Indonesia.

Given the economic importance of craft industry in the economy of Indonesia (see Figs. $3 \& 4$ above) and the recurring piratical acts off the waters of Indonesia (see Figure 2 above), it becomes imperative for Indonesian government to suppress piracy. It is argued that if piracy remains unchecked in the waters of Indonesia, it will grossly implicate on marine tourism, movement of tourists from one Indonesian island to another, including from one country to Indonesia, and importation of raw materials (including the exportation of craft products to the global craft market). Against this backdrop, the legal framework for tackling Indonesian piracy is robustly analysed below with a view to identifying lacunae in the antipiracy measures and subsequently proffer steps to take to repress the maritime crime in the country.

\section{Legal framework for curbing piracy off the coast of Indonesia}

\section{a. International regime}

Under international law, piracy consists of any illegal acts of violence committed for private ends by the crew or the passengers of a private ship on the high seas, against another ship outside the jurisdiction of any state. ${ }^{59}$ Among many limitations, it is observed that the above piracy definition applies only to the acts committed on the high seas or places outside jurisdiction of states. Consequently, it is argued that the geographic limitation of the definition excludes other features of modern piracy which sometimes occur both on the high seas and territorial waters of a state (especially at anchorages and ports).

57 Kazunobu Hayakawa, et al, Transportation costs in archipelagos: evidence from Indonesia (Institute of Developing Economies (IDE) Discussion Paper No. 756, 2019) 4. See also Kang H. Leung, Indonesia's summary transport assessment (ADB Papers on Indonesia No. 15, August 2016) 4.

58 The threat to navigation also includes tourists moving from one Indonesian island to another.

59 LOSC, art. 101. 
Beyond the fact that most data about piracy reveal acts of piracy and armed robbery against ships without distinguishing them, IMB defines piracy as 'any act of boarding or attempting to board any ship with the apparent intent or capability to use force in the furtherance of the act. ${ }^{60}$ This definition is apt in view of the nature of attacks against ships which mostly occurs off the coast of Indonesia and the need to assess the implications of piracy. For instance, piracy attacks in the waters of Indonesian involve ordinary forms of piracy and more sophisticated types, targeting stationary and anchoring vessels in crowded sea lanes as well as vessels sailing through narrow seas with many islands and heavy vessel traffic. Since Indonesia continues to be affected by piracy, it becomes imperative to have a comprehensive legal regime to secure sea-lanes for shipping as well as transhipment which remains a crucial part of the country's blue economy. ${ }^{61}$

To cure the territorial limitation in LOSC definition of piracy, the SUA Convention ${ }^{62}$ introduced no territorial strictures in the occurrence of piratical acts. Nonetheless, the SUA Convention did not extend universal jurisdiction to such attacks. It gives State Parties to the convention the power to prosecute people caught in their own territorial waters of acts of piracy committed in another country's jurisdiction. ${ }^{63}$ Also, it proffers extradition powers for the transfer of pirates from the arresting country to another country for the prosecution of the arrested pirates. ${ }^{64}$ This paper argues that the existence of the LOSC and the SUA Convention provides the legal framework for the government of Indonesia to repress piracy off its coast, especially in view of the potential threat of

60 Anamika A. Twyman-Ghoshal \& Glenn Pierce, 'The changing nature of contemporary maritime piracy', (2014) Brit. J. Criminol, doi:10.1093/bjc/azu019, 652,653 , quoting the IMB.

61 D. Dinarto, above n 28.

62 See also the Protocol of 2005 to the Convention for for the Suppression of Unlawful Acts against the Safety of Maritime Navigation, 14 October 2005. piracy to tourism and the craft industry in the country.

\section{b. National Regime}

It is imperative to state that domestic legal regime for suppressing piracy depends on countries ratifying and incorporating into their domestic laws conventions that criminalise piracy. This can be done through a monist system in which the convention becomes part of the domestic laws of the country or a dualist system which, on the other hand, requires the enactment of the convention into a domestic law. More so, incorporation of conventions into domestic legislation can be done through formal adoption vide parliamentary procedure, among other ways. ${ }^{65}$ It is observed that the Indonesian constitution is silent on the relationship between conventions and domestic laws. In all, Pulungan submits that 'an examination of Indonesian practice shows inconsistency in state practise when it comes to treaty implementation', ${ }^{66}$ which implicates on the enforceability of both the LOSC and the SUA Convention in the country.

In light of the foregoing, Indonesia has not only ratified the LOSC in Law No. 17 of 1985 , but also issued a range of laws and regulations to implement the Convention. ${ }^{67}$ For example, Law No. 6 of 1996 concerning Indonesian Waters; Law No. 17 of 2008 concerning Shipping; and Law No. 31 of 2004 concerning Fisheries as amended by Law No. 45 of 2009 were all enacted to adopt some of the provisions of the LOSC. Despite the above legislation, it is submitted that, presently, there is no law in Indonesia 'specifically implementing the LOSC provisions on piracy contained in articles 100-105. ${ }^{68}$

Notwithstanding the lack of law adopting the provisions of the LOSC on piracy in

63 SUA Convention, arts. 1, 4 and 6.

64 Ibid, arts. 6, 8 and 10.

65 R. W. Pulungan, above n 10 at 126.

66 Ibid.

67 Ibid at123.

68 Ibid at 124. 
Indonesia, the government of Indonesia, under its domestic law, criminalises piracy. Under Chapter XXIX titled "Crimes relating to navigation", the Indonesian Penal Code (known as Kitab Undang-undang Hukum Pidana - KUHP), which is under review, provides, inter alia, for unlawful seizure of an Indonesian ship. ${ }^{69}$ In fact, from articles 438 448, the KUHP makes elaborate provisions on piracy. For example, the KUHP provides for various acts of violence in articles 438-441 and prescribes 10 to 15 years imprisonment as punishment for these offences. Though it can be argued that the KUHP has expansive piracy provisions, a cursory look at the KUHP reveals that the "high seas" factor and the doctrine of universal jurisdiction are conspicuously missing. ${ }^{70}$ While this paper observes that there is an attempt to review the KUHP, ${ }^{71}$ it is important for the government of Indonesia to effectively implement the extant law.

\section{c. Soft laws}

It is trite that the United Nations General Assembly through its resolution advocated for cooperation at regional, multilateral, and bilateral levels in combating piracy. ${ }^{72}$ The key role regional cooperation plays in the fight against piracy has been given a fillip by the enactment of the International Maritime Organisation's (IMO) Code of Practice for Investigation of Crimes of Piracy and Armed Robbery against ships. Through the code, IMO shares its concern about piracy and urges states

69 KUHP, art. 448. For the application of the KUHP in piracy cases in Indonesia, see the cases of District Court Decision No 600/Pid.B/2015/PN Sgl. 3 December 2015 and District Court Decision No 524/Pid.B/2014/PN.BTM, 4 November 2015 cited in Adam J. Fenton \& Ioannis Chapos, 'Prosecuting pirates: maritime piracy and Indonesian law', 19(1) Aust. J. Asian L., 5-11.

70 R. W. Pulungan, above n 10 at 125.

71 See generally, Rachel Octora, 'Renewal of criminal law: draft of Indonesian criminal code, spirit of codification and its effects on law harmonization', (2016) 46(3) Journal Hukum \& Pembangunan 214, 214-232.

72 See generally, The United Nations General Assembly, Resolution adopted by the General to create and produce agreements as a tool to cooperate and combat piracy as well as armed robbery against ships. ${ }^{73}$ In spite of the above support for regional cooperation, the existence of Regional Cooperation Agreement on Combating Piracy and Armed Robbery against Ships in Asia (ReCAAP), and the consequences of piracy on the country, Indonesia is not part of ReCAAP which was established to combat piracy in Asia.

Given the fact that ReCAAP has shown keen interest in securing safe navigation in Asian waters and safeguarding the global shipping industry through collective efforts, it is argued that the government of Indonesia should join the anti-piracy group to secure its maritime domain with its attendant protection of the export and import sectors. This will ultimately prevent pirates from attacking vessels carrying craft items or raw materials and equipment needed for craft production. Moreover, as a model for regional cooperation, ${ }^{74}$ coupled with the inability of Indonesia to suo motu suppress piracy off its coast due to the vexed issue of sovereignty over the waters of the archipelago, ${ }^{75}$ this paper submits that ReCAAP could immensely facilitate and contribute in curbing piracy, especially in the Strait of Malacca.

\section{Causes of piracy and the effects of piracy in Indonesia's craft industry}

Under this subhead, the causes of piracy in the waters of Indonesia are reviewed. This

Assembly on 5 December 2008, A/RES/63/111, 12 February 2009.

73 IMO Code of Practice for Investigation of Crimes of Piracy and Armed Robbery against ships extends this concern and urged states to create and produce agreements as a tool to cooperate and combat piracy as well as armed robbery against ships, Resolution A.1025 (26) adopted on 2 December 2009 (Agenda item 10), A 26/Res.1025, 18 January 2010.

74 ReCAAP Information Sharing Center(ISC), Executive Director's Report 2016, 1.

75 Shishir Upadhyaya, 'Malacca Strait Security Initiative: potential for Indian navy's participation in the evolving regional security environment', (2009) 5(2) Maritime Affairs 47, 56. 
paper observes that the coast of Indonesia is the hub of piratical acts in Asia given its geographical feature as an archipelagic country, including the increasing number of ships that navigate through the Strait of Malacca, a choke point in the region. This warrants vessels to lower their acceleration as they navigate through the sea route. ${ }^{76}$ Young submits that piracy, particularly in Southeast Asia, is influenced by political, economic and social functions of the local people. ${ }^{77}$ Hence, it is imperative to identify and address the causes of piracy in the waters of Indonesia and their consequences.

\section{a. Causes of piracy off the coast of Indonesia \\ 1) Political unrest}

It is an open secret that the GAM plays a pivotal role in piracy attacks off the coast of Indonesia, especially in the Strait of Malacca. It is submitted that other domestic conflicts also contribute to the rise of piracy in Indonesia. Thus, the Papua separatist movement at the eastern end, the heightened religious conflict in Maluku and Poso, among others, created an enabling environment for piracy to thrive off the coast of Indonesia. ${ }^{78}$ More importantly, there is a suggestion that the GAM, which operates off North Sumatra, engages in piracy to finance its fight to create an independent Islamic state. ${ }^{79}$ In view of these factors, the paper concludes that political unrest contributes in sustaining piracy acts off the coast of Indonesia.

76 Joanne M. Fish, , A cross-disciplinary approach to the maritime security risk of piracy and lessons learned from agent-based modeling (a dissertation submitted to the Faculty of Old Dominion University in partial fulfillment of the requirements for the degree of Doctor of Philosophy, International Studies, Old Dominion University, December 2017), DOI: $10.25777 / \mathrm{spk} 1-5 \mathrm{~d} 03,47$.

77 Adam J. Young, 'Roots of contemporary maritime piracy in Southeast Asia', in D. Johnson \& $\mathrm{M}$.

\section{2) Asian financial crisis}

Undoubtedly, the 1997 Asian economic crisis played a role in the rise of contemporary piracy in Asia. It is beyond any reasonable contestation that the financial crisis in Asia in 1997 culminated in high rate of unemployment and poverty as most business and financial transactions were put paid. Moreover, the consequences of the financial crisis to the labour market in Indonesia extended to some subnational regions more than others. Accordingly, in Indonesia, it has been reported that the impact was worst in Java, "where approximately two thirds of the population live and which was previously prosperous', 80 thereby creating an enabling environment for piracy to thrive. In view of that, it is submitted that one of the consequences of poverty and unemployment occasioned by the Asia financial crisis, especially in Indonesia, is piracy. Thus, in a purported bid to eke out a living, some Indonesians, especially fishermen and the so-called freedom fighters, became pirates.

\section{3) Poverty}

As discussed above, consequent upon the widespread poverty exacerbated by the 1997 Asian economic crisis, Baird argues that poverty played a contributory role in the rise of piracy with the purported attraction of quick gains for low risk. ${ }^{81}$ It has been submitted that Indonesia was adversely affected by the financial crisis more than

Valencia (eds.) Piracy in Southeast Asia: status, issues and responses (ISEAS Singapore 2005) 2.

78 S. Febrica, above n 51 at 61-62.

79 R. W. Pulungan, above n 10 at 59.

80 James C. Knowles, et al., Social consequences of the financial crisis in Asia, (Economic Staff Paper No. 60, Asian Development Bank, 1999) 8.

81 Rachel Baird, Transnational security issues in the Asian maritime environment: fisheries and piracy, 2 <https://eprints.usq.edu.au/19493/1/Baird_ADF_20 10_PV.pdf $>$ accessed 5 August 2019. 
other Asian countries. ${ }^{82}$ This situation was particularly common among fishermen, the GAM and other groups that purported to be fighting for the liberation of their members in Indonesia. Moreover, a comprehensive research has found that poverty in the fishing subsector and piracy off the coast of Indonesia are interwoven, which suggests that when there is a depletion in the harvest of fish which leads to poverty among the fishermen, the fishermen become pirates to eke out a living. ${ }^{83}$

\section{4) Unemployment}

Aside from poverty, one of the consequences of the 1997 Asian economic crisis was a heightened level of unemployment in Asia. In view of Indonesia, the Asian economic crisis aggravated the level of unemployment in the country. It was reported that due to the Asian financial crisis, there was 'a dramatic rise in unemployment and 6.4 million people were laid off in 1998. ${ }^{84}$ As observed by Hastings, 'an increase in economic privation (such as through a downturn in the economy or a decrease in fishing stocks or unemployment ${ }^{85}$ ) could lead to an increase in unsophisticated pirate attacks' 86 , specifically in Indonesia. It has been observed that the "roots of contemporary piracy...in Southeast Asia can be found in the socio-economic and political environments of the states in the region' 87 which encouraged unemployment.

82 Reiny Iriana \& Fredrik Sjoholm, 'Indonesia's economic crisis: contagion and fundamentals', (2002) The Developing Economies 135, 135.

83 See generally, S. Axbard, above n 46.

84 Djoko Hartono \& David Ehrmann, The Indonesian economic crisis and its impact on educational enrolment and quality, (Institute of Southeast Asian Studies, Singapore, No. 7, May 2001) 3.

85 The italicised words by this author.

${ }^{86}$ Justin V. Hastings, The return of violent maritime organizations to Southeast Asia, 6

\section{5) Inability to join ReCAAP}

It is observed that in spite of the general agreement that Southeast Asian maritime security is in the interest of all countries which presupposes a greater cooperation, there is a rift in the position of some of the countries that are greatly affected by piracy in the region. This arises due to the penchant of some countries to manipulate the course of events in the region in their own interests. Consequently, Teitler submits that the 'reluctance of the countries in the region to co-operate against pirates, presents these rogues in effect with sanctuaries. Too weak themselves to patrol extensive coastal areas in border regions;' ${ }^{88}$ it appears that Indonesian government, for example, has declined to permit navies from neighbouring countries entrance into its waters to engage in hot pursuit of pirate ships. ${ }^{89}$

\section{6) Inadequate legal regime}

The pivotal role of having a comprehensive piracy legal framework in combating piratical acts cannot be taken for granted. This arises as a result of the need to properly arrest pirates, prosecute them in local courts while protecting their fundamental human rights, and subsequently incarcerate them according to the punishment contained in domestic laws. Despite the existence of the LOSC and the SUA convention in suppressing piracy, the government of Indonesia has not domesticated the provisions of these conventions. While there are provisions

<http://web.isanet.org/Web/Conferences/HKU2017 -s/Archive/bf3a2acd-a173-4d3e-8c50cd96d91773df.pdf $>$ accessed 8 August 2019.

87

Roderick Chia, et al, Maritime predations in the Malacca Straits: treading new waters (Centre for Non-Traditional Security (NTS) Studies, NTS Insight, August/1, 2009), 3.

88 Ger Teitler, 'Piracy in Southeast Asia. A historical comparison', (2002) 1(1) Mast 5, 73-74.

89 Ibid. 
in the KUHP which crimminalise piracy and punish pirates, it is argued that these provisions are not within the ambit of contemporary piracy that occurs off the coast of Indonesia. For example, the KUHP is conspicuously silent on piracy act that occurs on the high seas.

\section{7) Weak maritime domain awareness}

Given the nature of Indonesia's geographical location as a large maritime and archipelagic state in Asia, it becomes increasingly difficult for the country to effectively monitor its coast. To adequately monitor the coast of Indonesia, funds, human resources, and state of the art facilities are required to have effective maritime domain awareness. Consequently, in the absence of sufficient funds, inadequate trained human resources, and insufficient modern facilities in Indonesia, there will be weak maritime domain awareness within the coast of the country with its attendant effect on piracy in the region. ${ }^{90}$ This paper argues that the combined implication of the plethora of maritime agencies and inadequate funds and modern facilities in Indonesia is a dearth of maritime domain awareness which could incentivise the pirates with its attendant effect on the craft industry in the country.

\section{8) Corruption}

In light of the above, it has been argued that to compensate for the government inability to fund maritime security in Indonesia, the security

90 he consequences of inadequate human and material resources to protect the coast of Indonesia have been a source of concern more than a decade ago. See Hasjim Djalal, 'Piracy in South East Asia: Indonesian \& regional responses', (2004) 1 (3) Indonesia Journal of International Law, 419, 422423.

91 Carolin Liss, The privatisation of maritime securitymaritime security in Southeast Asia: between a rock and a hard place?, (Asian Research Centre, Working paper No. 141, February 2007), 8. agencies have not only engaged in private enterprises but also involved in piracy. ${ }^{91}$ Corruption in Indonesia, which is rife and has amplified piracy in the region, takes place when corrupt customs officials, port employees, or crewmembers divulge information on ship movements and cargo manifests to pirates. ${ }^{92}$ It appears that corruption is the lubricant that oils the linkage between piracy and elections in Indonesia. Aside from corrupt government officials that collude with pirates, corrupt seafarers, clearing agents, and port workers aid and abet pirates in perpetuating piracy acts off the coast of Indonesia. This corrupt culture is, in part, facilitated by the number of government agencies operating in the maritime sector ${ }^{93}$ that are susceptible to accepting bribes from pirates, thereby reducing the country's ability to curb piracy. ${ }^{94}$

\section{b. Effects of piracy in the Indonesian craft industry}

\section{1) Humanitarian effect}

The grave experiences of seafarers and fishermen due to piracy off the waters of Indonesia cannot be overemphasised. For instance, the release on the 19th of January 2019, two Indonesian fishermen who were held in captivity for over a year by the Abu Sayyaf Group (ASG) shows the humanitarian effect of piracy in Indonesia. ${ }^{95}$ Though it was reported that the crew did not suffer any injuries or there was no information to confirm that, 96 this paper argues that the

92 Daxecker \& Prins, above n 40 at 379.

93 B. Suseto, above n 49.

${ }^{94}$ L. Stach, above n 13 at 726.

95 ReCAAP/ISC, Annual Report 2018: Piracy and Armed Robbery against Ships in Asia, 3 January 2019, 16 <http://www.recaap.org/resources/ck/files/reports/a nnual/ReCAAP\%20ISC\%20Annual\%20Report\%20 2018.pdf $>$ accessed 8 August 2019.

96 Ibid, at 35-36. 
psychological trauma of being abducted and treated inhumanely by pirates are some of the reasons to repress piracy in any region. Regarding seafarers, on 5 th December 2018, an Indonesian crew of fishing trawler was rescued by the Philippine authorities in Barangay Bual in Luuk, Luuk in Sulu. ${ }^{97}$ According to report, 3 percent of Indonesian seafarers were exposed to piracy incidents in 2018. ${ }^{98}$ Hence, if a cruise ship was hijacked off the coast of Indonesia, foreign tourists may be discouraged from visiting Indonesia for tourism with it attendant effect on the craft industry in the country.

\section{2) Economic effect}

As stated above, report reveals that the complexity of shipping patterns and the nature of regional responses make it difficult to estimate aggregate cost of piracy in Southeast Asia, especially in Indonesia. ${ }^{99}$ In spite of that, it has been implied that significant additional costs are directly linked to counterpiracy measures like information sharing and military cooperation. ${ }^{100}$ While there may be no information suggesting economic loss on the part of the shipping company and the crew, report reveals that cash/property, engine spares, stores, and unsecured items are stolen by the pirates off the coast of Indonesia. ${ }^{101}$ In 2017 OBP report

97 Ibid at 16.

98 Lydelle Joubert, The state of maritime piracy 2018: assessing the human cost, (OBP Report, One Earth Future, Broomfield Co, USA 2018), 15.

99 Ibid.

100 Giacomo Morabito, 'Dangerous waters: the economic impacts of maritime piracy', Ph.D. Program: 2014-2016, Department of Economic, University of Messina, 39 <https://iris.unime.it/retrieve/handle/11570/310457 1/147896/GIACOMO\%20MORABITO\%20-\%20T hesis $\% 20 \% 28 \mathrm{PhD} \% 20 \mathrm{in} \% 20$ Economics $\% 20-\% 20$ University \%20of\%20Messina\%29.pdf > accessed 8 August 2019.

${ }^{101}$ ReCAAP/ISC, above n 95 at 36. summarised a limited economic cost of piracy in Asia thus: Malaysian Maritime Enforcement Agency (MMEA) US\$23,138,010, stolen ship stores, crew belongings, and cargo US\$ 6,320,920, ReCAAP budget US\$ 2,256,228, and lost wages US\$ 173,006. ${ }^{102}$ More pointedly, piracy may directly affect the craft industry in Indonesia if a vessel carrying craft products and craft raw materials and equipment was attacked by Indonesian pirates with its financial implications to the industry.

\section{3) Security effect}

From a security standpoint, the South China Sea and Malacca Strait are particularly vulnerable to pirate attacks and other transnational maritime crime due to the region's geography and importance as a strategic trade route. This creates narrow waterways that are densely packed with a number of cargo ships carrying goods, like craft products, and energy resources to Asia. ${ }^{103}$ The importance of securing these sea lanes that are connected to Indonesia is due to their economic significance to Asia and the rest of the world. As an illustration, 90 percent of the world's trade are conveyed by ship, 'one-third of the world's shipments moves through Southeast Asia's waters, and the 104 world's longest strait, the 500 mile long Malacca Strait, is the main seaway

${ }^{102}$ Maisie Pigeon, et al, 'The state of maritime piracy 2017: assessing the economic and human cost', (BPB Report, One Earth Future, Broomfield CO, USA, 2017, 20).

103 Aristyo R. Darmawan, ASEAN synergy to overcome challenges in maritime security: Indonesian perspective as the biggest archipelagic state in ASEAN

<https://www.academia.edu/33628836/ASEAN_SY NERGY_TO_OVERCOME_CHALLENGES_IN_ MARITIME_SECURITY_INDONESIAN_PERSP ECTIVE_AS_THE_BIGGEST_ARCHIPELAGIC_ STATE_IN_ASEAN $>$ accessed 8 August 2019.

104 The italicised word by this author. 
connecting the Indian Ocean and the South China Sea, and is particularly vulnerable to pirate attacks. ${ }^{105}$ This sea lane is particularly important to Indonesia because of the exportation of craft products and importation of raw materials and equipment needed in the craft industry in the country.

\section{4) Political effect}

It is pertinent to state that piracy thrives significantly in a weak or collapsed state. This has been exemplified by piracy incidents in Somalia and Nigeria. Research has proven that there is a connection between piracy and governance. For illustrative purposes, Daxecker, et al, opine that given the link between pirates and government officials, including the elite, piracy affects elections in some areas in Indonesia. ${ }^{106}$ Owing to the existing connection between pirates and government officials in Indonesia and the need to protect their interests, pirates engage in a number of piratical attacks to maintain their influence in government. Consequently, there is a strong indication 'that pirates elevate their attacks because they fear electoral interruption of their connections with incumbent politicians and public officials'. ${ }^{107}$ In closing, it is argued that the linkage between pirates and some corrupt government officials may lead to a situation where policies that would create an enabling environment for piracy to thrive are introduced in Indonesia, which potentially affects the craft industry.

105 A.R. Darmawan, above n 103.

106 Daxecker \& Prins, above n 40 at 379.

107 Ibid.

${ }^{108}$ I. Storey, above n 15 at 10.

109 Ibid.

110 For further readings on the Indonesian blues economy, see generally, Mohd. Agoes Aufiya,

\section{c. Measures to curb Indonesian piracy}

It is argued that since the early 2000s, the counter-piracy measures in Southeast Asian countries like enhanced legal regime under national jurisdiction, coordinated operations among their navies and coast guards, existence of information sharing networks, 'and accepted capacity-building support from non-regional states' 108 have significantly reduced the number of piracy acts in the region. Nevertheless, it is observed that in spite of these positive developments, over the years the number of reported incidents of piracy and armed robbery against ships has been high ${ }^{109}$ off the coast of Indonesia. Below are some steps that should be taken by the government of Indonesia to repress piracy off its coast to obviate its potential impact on the country's craft industry.

\section{1) Effective implementation of the 2017 maritime policy}

In 2014, newly elected Indonesian President Joko Widodo introduced the Global Maritime Fulcrum (GMF) to strengthen the maritime security for economic development of the country: blue economy. The effective implementation of GMF, especially in relation to marine culture, marine resources, archipelagic connectivity, maritime diplomacy and naval development is key to repressing piracy off the country's waters. ${ }^{110}$ In a similar vein, the National Ocean Policy 2017, which provided comprehensive roadmaps and policy guidelines to fulfil Indonesian maritime vision, has the blue economy included as one of the administration's main agendas. 111 Effective implementation of the 2017 policy would go a long way to curb

'Indonesia's global maritime fulcrum: contribution in the Indo-Pacific Region', (2017) 6(2) Andalas Journal of International Studies 143, 143-159.

111 See Presidential Decree of the Republic of Indonesia No. 16 of 2017. 
piracy in the waters of Indonesia. This is important because it not only focuses on securing the maritime environment but also protects the culture and the tourism industry, which are important components of the craft industry in Indonesia.

\section{2) Domestication of extant conventions on piracy}

In addition to the above, it is imperative for Indonesia to domesticate maritime security conventions that criminalise piracy. Against this backdrop, the LOSC and the SUA Convention should be domesticated. Despite the existence of a domestic law that criminalises piracy in Indonesia, this paper is of the view that the provisions of the law are limited; therefore, ineffective in curbing contemporary piracy. For example, the KUHP stipulations do not extend to piracy act committed on the high seas. The import of this limitation is that piratical act that occurs on the high seas will not be prosecuted in the country. Consequently, the KUHP should be amended to extend piracy to include violence against ships that occurs on the high seas. Besides, the extradition provision in the SUA Convention means that pirates arrested by Indonesia can be extradited to other countries for possible prosecution, which would contribute to curbing piracy off the coast of Indonesia. Aside from domesticating and implementing maritime security instruments, it is imperative that Indonesian government encourages Indonesian shipping companies and foreign shipping companies to adhere strictly to soft laws like the Best Management Practices (BMP) against pirates.

\section{3) Efficient and comprehensive maritime institutions}

Given the country's geographical position and the fact that it is the largest archipelago in the world, it becomes necessary for Indonesia to secure its waters. Moreover, Indonesia has a lot of natural resources, including crafts, which require a secured maritime sector for their exportation. As a consequence, a well-funded, well-equipped, and welltrained navy, BAKAMLA, and military police are necessary to curb piracy off the coast of Indonesia. To introduce an effective and efficient institutional regime in Indonesia's maritime sector, the number of maritime agencies in the country should be reduced. This will limit corruption and overlapping functions that could impede the monitoring and regulation of the coast of the country. More importantly, the funds and equipment can be properly managed among relevant maritime security and regulatory agencies in the country.

\section{4) Membership of ReCAAP and other regional organisations}

Whereas Indonesia is a member of the joint naval patrol unit, Malacca Straits Patrol (MSP) (other members include Malaysia, Singapore, and Thailand) to monitor activities in the Straits of Malacca and Singapore, it is equally necessary to join ReCAAP. Arguably, ReCAAP has been the most successful regional institution that has contributed in the reduction of piracy, especially in Asia. It is beyond any iota of doubt that ReCAAP, through its ISC, has enhanced information sharing that has led to timely response to attacks or avoidance of piratical attacks. More so, the monitoring of the waters in Asia and conducting training exercises among member states have greatly enhanced the preparedness of domestic maritime security and regulatory agencies in Asia. Against this backdrop, it becomes imperative for Indonesia to become a member of this regional group. 


\section{5) Robust economic development}

In light of the effect of the 1997

Asian financial crisis which led to massive unemployment and poverty across many countries in Asia, which prompted the rise of piracy in the region, the need to introduce and sustain a robust economic development in Indonesia becomes a condition sine qua non. More importantly, the government of Indonesia's perceived political marginalisation and socioeconomic inequalities, especially in relation to the Aceh ethnic group who are mostly fishermen, should be stopped. It is imperative to create and increase economic opportunities for the less developed ethnic groups to prevent them from becoming pirates. In light of that, the economic growth in Indonesia under this present administration should be commended, ${ }^{112}$ while more efforts, especially funds, should be channelled toward cultural heritage conservation, tourism, the creative economy, and the craft industry.

\section{6) Political reconciliation}

The role of political instability in the emergence of piracy cannot be overemphasised. For illustrative purposes, the absence of government in Somalia contributed in the rise of piracy in the Gulf of Aden and Indian Ocean. Similarly, the current spate of piracy in the Gulf of Guinea, particularly off the coast of Nigeria, is as a result of insurgence and other transnational crime in Nigeria. Thus, using the GAM

112 See generally, Indonesia economic outlook, (Macroeconomic Analysis Series, LPEM FEB UI, Universitas Indonesia, 2019).

113 The attempt to bring about political reconciliation though not completely achieved is a commendable step. It is

expected that the current government will strengthen the structure that will lead to a lasting reconciliation in

Indonesia. Se generally, 'Indonesia Country Report', BTI 2016 insurgency as a case study in Indonesia, it is imperative that there should be peace and reconciliation between the government and the insurgent groups. In light of that, the efforts of Indonesian government to reconcile all the factional groups in the country are steps in the right direction. ${ }^{113}$ It is imperative that all the ethnic groups in Indonesia should be given equal opportunity to participate in politics and engage in socioeconomic activities in the country.

\section{7) Extension of hot pursuit}

It has been suggested that expanding the right of hot pursuit through bilateral or multilateral agreement as done in suppressing piracy off the coast of Somalia, especially among the countries off the Strait of Malacca is a step in the right direction. ${ }^{114}$ This is pertinent considering the existing overlapping maritime boundaries among the three contending countries: Indonesia, Malaysia, and Singapore. This paper suggests that the government of Indonesia should not only expand the doctrine of hot pursuit to countries within the Strait of Malacca but to other Asian countries, especially the navies of the countries in Southeast Asia. Such collaborative efforts between Indonesia navy and the navies of other Southeast Asian countries should be adopted. Similarly, the existing MSP should be used as a platform to structure a hot pursuit agreement among the member states that would benefit them and contribute in suppressing piracy off the

<https://www.bti-

project.org/fileadmin/files/BTI/Downloads/Reports/ 2016/pdf/BTI_2016_Indonesia.pdf> accessed 4 March 2020.

114 Jacqueline J.F. Espenilla, 'Expanding the Right of Hot Pursuit: challenges for cooperative maritime law enforcement between the Philippines and Indonesia', (2017) 9 (1) International Journal of maritime Affairs and Fisheries, 1, 8. 
coast of Indonesia; thereby preventing its potential effect on the craft industry in the country.

\section{CONCLUSION}

Piracy off the coast of Indonesia is like the "sword of Damocles" hanging over the development of the country's maritime industry with arguably far-reaching implications on the craft industry in the country. As a riparian state, shipping is a cardinal aspect of the economic development of Indonesia. Additionally, the plethora of cultures and cultural heritage due to the number of ethnic groups in Indonesia makes the craft industry a significant part of the country's economic renaissance. To that end, the development of the art-craft industry, including tourism and the creative economy, relies on secured maritime environment. However, piracy in the waters of Indonesia has always been a recurring decimal with its implications on the humanitarian, socio-political, and economic development of the country. Given the astounding consequences posed by piracy in the craft industry in Indonesia, it becomes politic for the government of Indonesia to curb the crime by implementing the antipiracy measures submitted above. By introducing these measures, piracy off the coast of Indonesia will be suppressed and the threat of piratical attacks on craft and craft related vessels will be avoided.

\section{REFERENCES}

\section{Books}

BMP 4: Best Management Practices for Protection against Somalia based pirates", (Version 4 - August 2011, Whiterby Publishing Group Ltd, 2011).

Pavitta, Fryza P., et al (eds.), Craft (Simpul Group: Jakarta, 2019).

OPUS, Creative economy-outlook 2019 (BEKRAF, Jakarta, 2018)

\section{Chapters in Books}

Young, Adam J., 'Roots of contemporary maritime piracy in Southeast Asia', in D.
Johnson \& M. Valencia (eds.) Piracy in Southeast Asia: status, issues and responses (ISEAS Singapore 2005) 2.

\section{Statutes}

Indonesian Penal Code (Kitab Undang-undang Hukum Pidana).

\section{Presidential Regulations}

National Industry Policy No. 28, 2008, Presidential Regulation No. 72, 2014.

Presidential Decree of the Republic of Indonesia No. 16 of 2017.

Presidential Instruction No. 6 of 2009.

Presidential Regulation No. 92 of 2011.

Presidential Regulation No. 26, 2012.

\section{Conventions}

Convention for the Suppression of Unlawful Acts against the Safety of Maritime Navigation, adopted 10 March 1988, UNTS 1678.

United Nations Convention on the Law of the Sea, adopted in 1982 and came into force 1994, 21 ILM (1982), 1261.

Protocol of 2005 to the Convention for for the Suppression of Unlawful Acts against the Safety of Maritime Navigation, 14 October 2005.

\section{Journal articles}

AArief, Fadilah. H., 'Indonesian crafts: the overlooked potential of geographical indication', (2016) 2(3) International Journal of Culture and History 87, 87.

Arif, Muhamad and Yandry Kurniawan, 'Strategic culture and Indonesian maritime security', (2018) 5(1) Asia \& the Pacific Policy Studies, doi: 10.1002/app5.203, 77, 80.

Aufiya, Mohd. Agoes, 'Indonesia's global maritime fulcrum: contribution in the Indo-Pacific Region', (2017) 6(2) Andalas Journal of International Studies 143, 143-159.

Axbard, Sebastian, 'Income opportunities and sea piracy in Indonesia', (2016) 8 (2) American Economic Journal: Applied Economics 
Briandana, Rizki, et al, 'Promotion analysis of marine tourism in Indonesia: a case study', (2018) XXI (1) European Research Studies Journal, 602.

Chuta, Lakhimi J. \& Mrinmoy K. Sarma, 'Commercialization of traditional crafts of South and South East Asia: a conceptual model based on review of literature', (2016) 5(2) IIM Kozhikode Society \& Management Review.

Daxecker, Ursula E. \& Brandon C. Prins, 'The politicization of crime: electoral competition and the supply of marine piracy in Indonesia', (2016) 169 Policy Choice, DOI 10.1007/s11127-016-0374$\mathrm{z}$.

Djalal, Hasjim, 'Piracy in South East Asia: Indonesian \& regional responses', (2004) 1 (3) Indonesia Journal of International Law.

Espenilla, Jacqueline J.F., "Expanding the Right of Hot Pursuit: challenges for cooperative maritime law enforcement between the Philippines and Indonesia", (2017) 9 (1) International Journal of maritime Affairs and Fisheries.

Fenton, Adam J. and Ioannis Chapos, 'Prosecuting pirates: maritime piracy and Indonesian law', 19(1) Aust. J. Asian L., 511.

Harrelson, Jill, "Blackbeard meets blackwater: an analysis of international conventions that address piracy and the use of private security companies to protect the shipping industry", (2010) 5(2) American University International Law Review, 283, 284.

Hastings, Justin V., 'Understanding maritime piracy syndicate operations', (2012) 21(4) Security Studies https://doi.org/10.1080/09636412.2012. 734234.

Iriana, Reiny \& Fredrik Sjoholm, 'Indonesia's economic crisis: contagion and fundamentals', (2002) The Developing Economies.

Nguyen C.M. \& Le T.Q., "Impact of piracy on maritime transport and technical solutions for prevention', 10 (01)
International Journal of Civil

Engineering and Technology 958, 959 (2019).

Nikolic, Nebojsa \& Eduard Missoni, 'Piracy on the high seas-threats to travelers', (2014) 20(5) Journal of Travel Medicine, DOI: $10.1111 / \mathrm{jtm} .12051$.

Octora, Rachel, 'Renewal of criminal law: draft of Indonesian criminal code, spirit of codification and its effects on law harmonization', (2016) 46(3) Journal Hukum \& Pembangunan.

Prange, Sebastian R., 'Asian piracy', (2017) Indian Ocean Studies, DOI: 10.1093/acrefore/9780190277727.013.3 2.

Riani, Asri Laksmi, et al, 'The acceleration of traditional Batik (creation and combination) through integrated management to support the acceleration in regional economic development', (2016) 4(4) Strategic Management Quarterly DOI: 10.15640/smq.v4n4a4.

Setyorini, Christina Tri, et al, 'Strengthening the internal factors of Batik cluster SMEs in Indonesia: a case of six districts in South-Central Java', (2013) 3(1) International Journal of Business, Humanities and Technology.

Stach, Lukasz, 'Neverending story? Problem of maritime piracy in Southeast Asia', (2017) 7(12) International Journal of Social Science and Humanity.

Sulistiyono, A.B., et al, '4M study to support Indonesia's maritime tourism development', (2017) 11(4) The International Journal on Marine Navigation and Safety of Sea Transportation, DOI: 10.12716/1001.11.04.20

Suseto, Buddy, et al, "The need to reform Indonesia's maritime strategy: a review", (2018) 50(2) Indonesian Journal of Geography. DOI: http://dx.doi.org/10.22146/ijg.27954.

Teitler, Ger, 'Piracy in Southeast Asia. A historical comparison', (2002) 1(1) Mast 5 . 
Tumbarska A., 'Maritime piracy and armed robbery evolution in 2008-2017', (2018) II(1) International Scientific Journal Security \& Future 18, 19.

Twyman, Anamika A. -Ghoshal \& Glenn Pierce, 'The changing nature of contemporary maritime piracy', (2014) Brit. J. Criminol, doi:10.1093/bjc/azu019.

Upadhyaya, Shishir, 'Malacca Strait Security Initiative: potential for Indian navy's participation in the evolving regional security environment', (2009) 5(2) Maritime Affairs.

Virkar, Anjali R. \& Prita D. Mallya, 'A review of dimensions of tourism transport affecting tourist satisfaction', (2018) IX(1) Indian Journal of Commerce \& Management Studies DOI: 10.18843/ijcms/v9i1/10.

Williamson, Hugh R., 'New thinking in the fight against marine piracy: financing and plunder pre-empting piracy before prevention becomes necessary', (2013) 6 Case Western Reserve Journal of International Law.

Zahidi, Syaprin M., 'Batik as Indonesian public diplomacy in ASEAN Economic Community (AEC)', 3(2) International Journal of International Relations, Media and Mass Communication Studies 1, 8 (2017).

\section{UNGAR}

The United Nations General Assembly, Resolution adopted by the General Assembly on 5 December 2008, A/RES/63/111, 12 February 2009.

\section{Reports}

ICC/IMB Piracy and armed robbery against ships: report for the period 1 January 31 December 2019, January 2020, hereafter referred to as the "ICC/IMB Piracy Report for 2019”, 18.

ICC International Maritime Bureau (IMB) Piracy and armed robbery against ships: report for the period 1 January - 31 December 2018, January 2019.

\section{Soft law}

IMO Code of Practice for Investigation of Crimes of Piracy and Armed Robbery against ships extends this concern and urged states to create and produce agreements as a tool to cooperate and combat piracy as well as armed robbery against ships, Resolution A.1025 (26) adopted on 2 December 2009 (Agenda item 10), A 26/Res.1025, 18 January 2010.

\section{Conference/seminar papers/dissertations}

Burlando, Alfredo, et al, The trade consequences of maritime insecurity: evidence from Somali piracy, (Munich Personal RePEc Archive (MPRA), 24 October 2014), 2.

Chia, Roderick, et al, Maritime predations in the Malacca Straits: treading new waters (Centre for Non-Traditional Security (NTS) Studies, NTS Insight, August/1, 2009), 3.

Febrica, Senia, 'Explaining Indonesia's participation in maritime security cooperation', (submitted in fulfillment of the requirements for the degree of Ph.D, School of Social Sciences, University of Glasgow, 2014), 61-62.

Financing opportunities in Indonesia's creative industry: final report, (IPSOS Business Consulting, April 2018), 16.

Fish, Joanne M., A cross-disciplinary approach to the maritime security risk of piracy and lessons learned from agentbased modeling (a dissertation submitted to the Faculty of Old Dominion University in partial fulfillment of the requirements for the degree of Doctor of Philosophy, International Studies, Old Dominion University, December 2017), DOI: 10.25777/spk1-5d03, 47.

Gerke, Solvay \& Hans-Dieter Evers, 'The strategic importance of the Straits of Malacca', (Nusantara Papers No. 2, 2016), 2. 
Hartono, Djoko \& David Ehrmann, The Indonesian economic crisis and its impact on educational enrolment and quality, (Institute of Southeast Asian Studies, Singapore, No. 7, May 2001), 3. Hayakawa, Kazunobu, et al, Transportation costs in archipelagos: evidence from Indonesia (Institute of Developing Economies (IDE) Discussion Paper No. 756, 2019) 4.

Historical \& Culture (Sumatera Utara eBrochure).

Hribernik M., 'Multilateral counter-piracy cooperation in Southeast Asia: the role of Japan', (2017) 17(3) Pacific Forum CSIS Issues \& Insights, Honolulu, Hawaii, March 2017, 4.

Indonesia economic outlook, Macroeconomic Analysis Series, LPEM FEB UI, Universitas Indonesia, 2019.

Joubert, Lydelle, The state of maritime piracy 2018: assessing the human cost, (OBP Report, One Earth Future, Broomfield Co, USA 2018), 15.

$\mathrm{Ke}, \mathrm{Xu}$, Contemporary maritime piracy in Southeast Asia, (a thesis submitted for the Degree of Doctor of Philosophy Southeast Asian Studies Programme, National University of Singapore, 2006), 36-37.

Knowles, James C., et al. Social consequences of the financial crisis in Asia, (Economic Staff Paper No. 60, Asian Development Bank, 1999), 8.

Leung, Kang H., Indonesia's summary transport assessment, (ADB Papers on Indonesia No. 15, August 2016), 4.

Liss, Carolin, Assessing contemporary maritime piracy in Southeast Asia: trends, hotspots and responses, (Peace Research Institute Frankfurt (PRIF), PRIF Report No. 125, 2014), 18.

Liss, Carolin, The privatisation of maritime security- maritime security in Southeast Asia: between a rock and a hard place?, (Asian Research Centre, Working paper No. 141, February 2007), 8.

Morris, Lyle J. \& Giacomo P. Paoli, A preliminary assessment of Indonesia's maritime security threats and capabilities, (Rand Corporation, 2018), 15.

Oil and gas in Indonesia, (PWC Investment and Taxation Guide, May 2017).

Ollivaud, Patrice \& Peter Haxton., Making the most of tourism in Indonesia to promote sustainable regional development, (Economics Department Working Papers No. 1535, Organisation for Economic Co-operation and Development (OECD), 17 February 2019), 11.

Pigeon, Maisie, et al, The state of maritime piracy 2017: assessing the economic and human cost, (BPB Report, One Earth Future, Broomfield CO, USA, 2017), 20. Rheny W. Pulungan, 'The limitations of the international law on piracy and maritime terrorism: options for strengthening maritime security in the Malacca Straits', (submitted in total fulfilment of the requirements of degree of Doctor of Philosophy Melbourne Law School, the University of Melbourne, June 2014), 32. Raymond, Catherine Z.., Piracy in Southeast Asia: new trends, issues and responses, (Institute of Defence and Strategic Studies No. 89, Singapore, October 2006), 4.

Storey, Ian, 'Addressing the persistent problem of piracy and sea robbery in Southeast Asia', (2016) 30 Perspective, ISEAS Yusof Ishak Institute, 2.

Subagja, Iwan K., Creative industry competitiveness in Indonesia (study on creative industry map), International Conference on Sustainable Development Goals 2030 Challenges and its Solutions, 11-12 August 2017, pp. 157-159.

Travel \& Tourism: economic impact 2018 Indonesia, World Travel \& Tourism Council, March 2018.

\section{Online sources}

Baird, Rachel., Transnational security issues in the Asian maritime environment: fisheries and piracy, 2 <https://eprints.usq.edu.au/19493/1/Bair 
d_ADF_2010_PV.pdf> accessed 5 August 2019.

Bateman, Sam, Sea piracy: some inconvenient truths, 2010 , <https://www.peacepalacelibrary.nl/ebo oks/files/UNIDIR_pdf-art2960.pdf> accessed 31 July 2019.

Darmawan, Aristyo R., ASEAN synergy to overcome challenges in maritime security: Indonesian perspective as the biggest archipelagic state in ASEAN <https://www.academia.edu/33628836/ ASEAN_SYNERGY_TO_OVERCOM E_CHALLENGES_IN_MARITIME_S ECURITY_INDONESIAN_PERSPEC TIVE_AS_THE_BIGGEST_ARCHIPE LAGIC_STATE_IN_ASEAN> accessed 8 August 2019.

Darmawan, Aristyo R., Indonesia's global maritime fulcrum: how can traditional coastal communities benefit from it? <https://www.academia.edu/33642162/I NDONESIAS_GLOBAL_MARITIME_ FULCRUM_HOW_CAN_TRADITION AL_COASTAL_COMMUNITIES_BE NEFIT_FROM_IT $>$ accessed 8 August 2019.

Dinarto, Dedi, 'Indonesia's blue economy initiative: rethinking maritime security challenges', RSIS Commentary No. 206, $1 \quad$ November 2017 <https://www.rsis.edu.sg/wpcontent/uploads/2017/11/CO17206.pdf > accessed 26 July 2019.

Ikrami, Hadyu \& Leonardo Bernard, Indonesia's maritime law: national enforcement \& regional cooperation, 5th APOLIA Conference, 16 June 2017, Da Nang, Vietnam <https://cil.nus.edu.sg/wpcontent/uploads/2017/08/Ikrami_Bernar d_2017-APOLIA-

Conference_FINAL.pdf $>$ accessed 30 November 2019.
Indonesia Country Report, BTI 2016 $<$ https://www.btiproject.org/fileadmin/files/BTI/Downlo ads/Reports/2016/pdf/BTI_2016_Indone sia.pdf> accessed 4 March 2020.

Indonesia sourcing: craft gifts 2018, Hinrich Foundation, 2019 $<$ https://newsourcingmarkets.com/indon esia-sourcing-handicrafts-2018/> accessed 22 May 2019.

Hastings, Justin V., The return of violent maritime organizations to Southeast Asia, <http://web.isanet.org/Web/Conferences /HKU2017-s/Archive/bf3a2acd-a1734d3e-8c50-cd96d91773df.pdf> accessed 8 August 2019.

Malisan, Jhon., Intermodal integration in Indonesia, Research \& Development Agency, Ministry of Transportation <http://www.uncrd.or.jp/content/docum ents/7EST-P3-3.pdf $>$ accessed 5 September 2019.

Morabito, Giacomo., Dangerous waters: the economic impacts of maritime piracy, Ph.D. Program: 2014-2016, Department of Economic, University of Messina, 39 <https://iris.unime.it/retrieve/handle/115 70/3104571/147896/GIACOMO\%20M ORABITO\%20-\%20Thesis\%20\%28Ph D\%20in\%20Economics\%20-\%20Unive rsity\%20of\%20Messina\%29.pdf> accessed 8 August 2019.

ReCAAP/ISC, Annual Report 2018: Piracy and Armed Robbery against Ships in Asia, 3 January 2019, 16 <http://www.recaap.org/resources/ck/fil es/reports/annual/ReCAAP $\% 20 I S C \% 20$ Annual\%20Report\%202018.pdf> accessed 8 August 2019.

The roots of piracy in Southeast Asia, APSNet Policy Forum, 22 October 2007, 2 https://nautilus.org/apsnet/the-roots-ofpiracy-in-southeast-asia/ accessed 26 July 2019. 